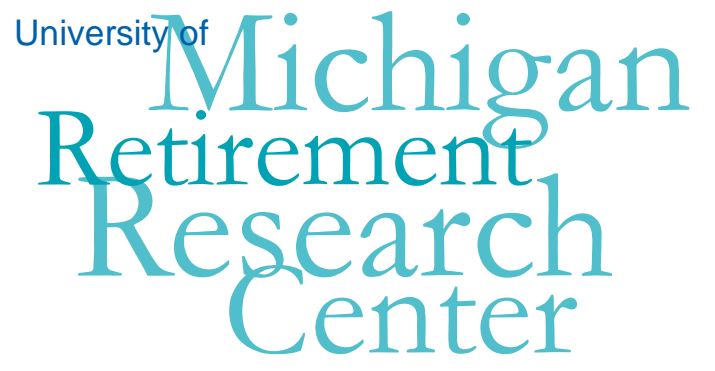

Working Paper

WP 2012-266

\title{
Exchanging Delayed Social Security Benefits for Lump Sums: Could This Incentivize Longer Work Careers?
}

Jingjing Chai, Raimond Maurer, Olivia S. Mitchell and Ralph Rogalla

\begin{tabular}{|l|l|}
\hline $\mathrm{M}$ & $\mathrm{R}$ \\
\hline $\mathrm{R}$ & $\mathrm{C}$ \\
\hline
\end{tabular}

Project \#: UM12-08 



\title{
Exchanging Delayed Social Security Benefits for Lump Sums: Could This Incentivize Longer Work Careers?
}

\author{
Jingjing Chai \\ Goethe University \\ Raimond Maurer \\ Goethe University \\ Olivia S. Mitchell \\ The Wharton School, University of Pennsylvania \\ Ralph Rogalla \\ Goethe University \\ October 2012 \\ Michigan Retirement Research Center \\ University of Michigan \\ P.O. Box 1248 \\ Ann Arbor, MI 48104 \\ WWw.mrrc.isr.umich.edu \\ (734) 615-0422
}

\section{Acknowledgements}

This work was supported by a grant from the Social Security Administration through the Michigan Retirement Research Center (Grant \# 5 RRC08098401-04-00). The findings and conclusions expressed are solely those of the author and do not represent the views of the Social Security Administration, any agency of the Federal government, or the Michigan Retirement Research Center.

\section{Regents of the University of Michigan}

Julia Donovan Darrow, Ann Arbor; Laurence B. Deitch, Bloomfield Hills; Denise Ilitch, Bingham Farms; Olivia P. Maynard, Goodrich; Andrea Fischer Newman, Ann Arbor; Andrew C. Richner, Grosse Pointe Park; S. Martin Taylor, Gross Pointe Farms; Katherine E. White, Ann Arbor; Mary Sue Coleman, ex officio 


\title{
Exchanging Delayed Social Security Benefits for Lump Sums: Could This Incentivize Longer Work Careers?
}

\begin{abstract}
Social Security benefits are currently provided as a lifelong benefit stream, though some workers would be willing to trade a portion of their annuity streams in exchange for a lump sum amount. This paper explores whether allowing people to receive a lump sum as a payment for delayed retirement rather than as an addition to their lifetime Social Security benefits might induce them to work longer. We model the factors that influence how people trade off a Social Security stream for a lump sum, and we also examine the consequences of such tradeoffs for work, retirement, and life cycle wellbeing. Our base case indicates that workers given the chance to receive their delayed retirement credit as a lump sum payment would boost their average retirement age by 1.5-2 years. This will interest policymakers seeking to reform the Social Security system without raising costs or cutting benefits, while enhancing the incentives to delay retirement.
\end{abstract}

\section{Authors' Acknowledgements}

The research reported herein was performed pursuant to a grant from the Social Security Administration (SSA) to the Michigan Retirement Research Center (MRRC) as part of the Retirement Research Consortium. Additional research support was provided by the Deutsche Forschungsgemeinschaft (DFG), the Gennan Investment and Asset Management Association (BYI), the Pension Research Council at The Wharton School of the University of Pennsylvania, and the Metzler Exchange Professor program. Opinions and errors are solely those of the autl10rs and not of the institutions with whom the authors are affiliated. (C) 2012 Chai, Maurer, Mitchell, and Rogalla. All rights reserved. 


\title{
Exchanging Delayed Social Security Benefits for Lump Sums: Could This Incentivize Longer Work Careers?
}

\author{
Jingjing Chai, Raimond Maurer, Olivia S. Mitchell, and Ralph Rogalla
}

Deciding when to retire and claim Social Security benefits is one of the most important financial decisions that people make. Traditionally, claiming triggers the beginning of a lifelong annuity payment. Yet if workers who delayed claiming were offered a lump sum instead of an actuarially-adjusted deferred annuity, it is possible that at least some would decide to work longer. This paper models the factors that influence whether individuals would be willing to trade off delayed Social Security benefits in exchange for a lump sum. Additionally, we examine the consequences of providing a lump sum reward in lieu of an actuarially-adjusted annuity for work, retirement, and life cycle well-being.

Economic theory suggests that retirees value lifelong income benefit streams that protect them from running out of money in old age (Yaari, 1965; Davidoff et al., 2005; Mitchell et al., 1999). An implication of the theory is that most risk-averse individuals would be expected to hold a substantial portion of their portfolios in annuitized assets. Nevertheless, empirical evidence suggests that many people value lump sum payouts over lifelong benefit streams (Brown et al., 2008; Warner and Pleeter, 2001). We explore these key outcomes by developing and implementing a realistically-calibrated life cycle model for forward looking rational agents with endogenous labor supply, saving, investment, and retirement decisions, that allows for timevarying investment opportunity sets and risky labor income.

The goal of this research is to evaluate whether this potential approach to Social Security reform would induce workers to retire later on a voluntary basis. We find that such a policy has the potential to increase retirement ages substantially, with little or no decline in welfare. Three 
factors help explain why the lump sum reward for deferred retirement can induce more work while not decreasing lifetime utility. First, many people would prefer to have a lump sum rather than an addition to their lifetime Social Security benefit, as this affords them flexibility over the timing of their consumption and leisure decisions. A second reason is liquidity driven: that is, if people desire to leave a stock of assets to their heirs, having a lump sum enhances this possibility. And third, financially sophisticated individuals able to participate in the equity market will find attractive the opportunity to invest some of their lump sum amounts.

Policymakers seeking ways to reform the Social Security system may be interested in our findings, since the actuarially fair lump sum for delayed retirement does induce some individuals to work longer voluntarily. In our base case, workers given the chance to receive their delayed retirement credit as a lump sum payment would boost their average retirement age by 1.5-2 years. Moreover, when the reform is implemented, this boosts the probability of working beyond the normal retirement age from $29 \%$ to $86 \%$ for the young, and from $4 \%$ to $49 \%$ for 60 -year olds. Results vary, of course, across individuals of different types: the effect is even larger for less riskaverse older households, while the most risk-averse respond least. Financially unsophisticated households (i.e., those who lack access to the equity market) are also relatively unresponsive to the lump sum option; even here, though, the less risk-averse still tend to work longer and retire later. Moreover, we show that such a lump sum policy would generally not detract from wellbeing: in the base case, young workers typically have virtually no change in lifetime utility, whereas older individuals gain slightly. Among the less financially sophisticated, both the young and the old experience little change.

It is worth noting that offering a lump sum equivalent in expected present value to the delayed retirement credit would be cost-neutral to the system, on average. Additionally, if older 
individuals worked longer voluntarily, this could enhance system solvency via additional payroll tax collections.

\section{Prior Studies}

This paper contributes to the research examining the effects of Social Security policies on labor supply. ${ }^{1}$ A number of studies in the portfolio choice literature have investigated how individuals might alter their work, investment, annuitization, and retirement decisions in response to change in Social Security benefits assuming a parameterization similar to that in the US Social Security system. ${ }^{2}$ Yet these analyses have not examined optimal household life cycle behavior with flexible work hours and retirement, to assess what might happen if people were afforded the opportunity to take part of their Social Security benefits as a lump sum instead of as a benefit flow.

Experimental research and survey evidence has suggested that a majority of workers would favor lump-sum payments over lifetime benefits, if these were approximately actuarially equivalent. Furthermore, there is some modest price sensitivity associated with this preference (Brown et al. 2008, 2011). Orszag (2001) discussed some important institutional design aspects of Social Security (e.g. computation of present values, spousal/widow benefits) and offered comments on how lump sum benefits might replace the delayed retirement (annuity) credit. His work provided some preliminary evidence that claiming probabilities could rise in response. Fetherstonhaugh and Ross (1999) reported that for 80 percent of their survey respondents, a lump-sum payment instead of an increase in annual benefit amounts due to delayed claiming

\footnotetext{
${ }^{1}$ See Feldstein and Leibman (2002) for a review, and most recently, Laitner and Silverman (2012).

${ }^{2}$ See Kotlikoff and Viceira (2008), Chai, Horneff, Maurer, and Mitchell (2011), and Chai, Maurer, Mitchell, and Rogalla (2012).
} 
would provide an incentive to claim later. Nevertheless, those studies focus specifically on the claiming decision (and how these decisions are framed), but they abstract from other important factors including preferences (risk aversion, leisure, impatience), the state of the business cycle, uncertainty with respect to labor income and capital markets, asset allocation, household saving, and health status. Most importantly, they assume that the claiming decision is independent of labor force participation. Therefore that research is silent on the likely impact of such lump-sum options on work hours, retirement ages, saving, and household well-being. Moreover, offering such lump-sums could potentially induce workers to delay retirement and claiming of Social Security benefits, which could enhance system sustainability. There has been no theoretical research on this topic to date.

\section{Methodology}

Our prior work on which we build this study developed, implemented, and calibrated a realistic discrete time life cycle model of endogenous work hours, retirement behavior, consumption, saving, and portfolio choice (c.f. Chai, Maurer, Mitchell, and Rogalla, 2012). Allowing for uninsurable labor income risk and capital market risk, this model incorporates individual risk aversion, time preferences, and leisure preferences, as well as borrowing constraint, and uncertain length of life. Preferences in each period are characterized by an isoelastic and time-separable power utility function defined over a composite good consisting of consumption $C_{t}$ and leisure $L_{t}$ at time $t$, and wealth $Q_{t}$ bequeathed to the next generation.

As is conventional in the theoretical literature, the relative importance of leisure and consumption is valued using a modified Cobb-Douglas function, which ensures that the elasticity of substitution between consumption and leisure is equal to one. The value function is given by: 


$$
V_{t}=\frac{\left(C_{t} L_{t}^{\alpha}\right)^{1-\rho}}{1-\rho}+\beta E_{t}\left(p_{t} V_{t+1}+\left(1-p_{t}\right) b \frac{\left(Q_{t+1}\right)^{1-\rho}}{1-\rho}\right)
$$

with terminal utility (at age 100) $V_{T}=\frac{\left(C_{T} L_{T}^{\alpha}\right)^{1-\rho}}{1-\rho}+\beta E_{T}\left(b \frac{\left(Q_{T+1}\right)^{1-\rho}}{1-\rho}\right)$. The parameter $p_{t}$ denotes the subjective probability of surviving to time $t+1$, given the consumer is alive at $t$. The parameter $\rho$ is the coefficient of relative risk aversion, and $\beta$ is the rate of time preference. Leisure preferences are governed by the parameter $\alpha$. The strength of the bequest motive is controlled by the parameter $b$. In each period, the individual must decide how much to work, consume, and invest in the capital market. Also the worker must decide when to retire and claim Social Security benefits. This problem is solved through backward induction of the value function. The optimal policies are then evaluated by conducting a Monte Carlo simulation (for further details see Appendix A). For the base case worker, preference parameters are set as follows: coefficient of relative risk aversion $\rho=5$, discount factor $\beta=0.97$, leisure preference value $\alpha=1.3$, and bequest strength $b=0$. The one-period survival rates $p_{t}$ are taken from the US 2000 population mortality table for females. ${ }^{3}$ In additional sensitivity analysis we vary preference parameters.

The stock and labor market processes are governed by a "regime-switching" process for the business cycle. Asset returns are characterized by either a 'normal' capital market (with low volatility/high expected returns) or a 'crisis' scenario (with high volatility/low expected returns). The deterministic component of the wage rate process and the labor income shock process follows Chai, Maurer, Mitchell, and Rogalla (2012). Housing-related expenditures are estimated using data from the Consumer Expenditure Survey (as described in Appendix B).

\footnotetext{
${ }^{3}$ Using a similar model framework; Chai, Horneff, Maurer, and Mitchell (2011) show that these parameter values replicate several empirical facts including the hump-shaped pattern of work hours, the two peaks in retirement rates, and the sizeable decline in consumption at retirement.
} 
We also implement a realistic approach to determining Social Security benefits, where the worker may claim a benefit between the early retirement age (ERA) of 62 and the late retirement age (LRA) of 70. If the worker claims prior to her normal retirement age (NRA), she receives a permanently lower benefit for life; if she claims later, her Social Security benefit payment is increased by the delayed retirement credit. For our alternative scenario, we examine how retirement behavior would change if the individual could take a part of her Social Security benefits as a lump sum payment, by working beyond the NRA. This lump sum payment would be equal, in present value terms, to the additional benefit stream paid to the worker claiming Social Security benefits after the NRA.

Several factors might be anticipated to lead people to favor a lump sum over an annuity stream. For instance, people might wish to leave a bequest, have a higher or lower discount rate, value leisure strongly, or be very risk-averse. Other influences could include changes in the retirement system such as a lower replacement rate and a higher normal retirement age. We also explore how financial sophistication might shape peoples' responses to the Social Security lump sum option versus the annuity. This takes into account the finding that many Americans lack knowledge of and easy access to sophisticated financial instruments such as equities (Lusardi and Mitchell, 2007; Gomes and Michaelides, 2005). ${ }^{4}$ Additionally we provide a welfare analysis that evaluates the extent to which the ability to convert deferred Social Security benefits into a lump sum can enhance worker well-being.

In what follows, we present results for individuals initially observed at age 20 , and separately at age 60. This allows us to explore the likely behavioral responses of older versus younger workers. We present two sets of results: in the base case, workers have access to the stock and the bond market, which we deem the financially sophisticated group. In an alternative

\footnotetext{
${ }^{4}$ Using a dataset on Swedish investors, Calvet, Campbell, and Sodini (2009) find empirical evidence that the share of risky assets held by households is strongly positively correlated with an index for financial sophistication.
} 
scenario, the analysis assumes that individuals can hold only bonds paying a safe return, but they have no access to equities. The model assumes that 20 -year olds hold no initial wealth. For 60 year olds, we estimate distributions of income and wealth-to-income ratios using the Health and Retirement Study (HRS) for single female households. ${ }^{5}$ To this end, we first group all households initially aged 60 into two categories: stockholders and non-stockholders. Then, within each household category, we drop the lower and upper labor income quartiles (to avoid data outliers). Hence, there are 50 labor income percentiles left (i.e., the $25^{\text {th }}-74^{\text {th }}$ percentiles). ${ }^{6}$ In order to specify distinct combinations of wealth-to-income ratios and labor income percentiles, we estimate average wealth-to-income ratios for each of the 50 income percentiles. We then simulate 10,000 life cycle paths for every combination of wealth-to-income ratios and income quantiles using optimal feedback controls obtained from the numerical optimization model. All results are reported as the average of 50,000 paths (i.e., $50 \times 10,000)$.

\section{Results}

Under the Social Security system's current rules, a worker who delays claiming her benefit until after the Normal Retirement Age (NRA) is entitled to a benefit increase of about $8 \%$ per year that retirement is deferred. ${ }^{7}$ In our model, under an actuarially fair lump-sum scheme, an individual who opted to work to age 66 instead of claiming benefits at age 65 would then receive a lump sum worth of about 1.2 times her age- 65 benefit, plus the age- 65 benefit stream for life.

\footnotetext{
5 The HRS (here we use waves one to ten) is a longitudinal panel study which surveys a representative sample of over 26,000 respondents age 50+ every two years; see http://hrsonline.isr.umich.edu/.

${ }^{6}$ This procedure generates wealth-to-income-ratios for stockholders (non-stockholders) with a mean value of 3.76 (1.31), and a standard-deviation of $1.7(0.75)$.

${ }^{7}$ The Social Security delayed retirement credit of $8 \%$ per year's delay was intended to be actuarially fair at the time the law was passed; this was consistent with average mortality tables at the time, as well as a $2.9 \%$ real assumed interest rate. In this paper we assume a real interest rate of $2 \%$, a rate more consistent with the current low interest rate regime. As Shoven and Slavov (2012) note, in such a case the delayed retirement credit of $8 \%$ per annum will be better than actuarially fair for most people, thus embodying additional incentives to defer retirement. To the extent this is true, the lump sums we compute are also better than actuarially fair with respect to the $2.9 \%$ assumption.
} 
Similarly, an individual deferring retirement even later, to age 70 , would receive a lump sum worth about 6 times the starting-age annual benefit payment, plus the age- 65 benefit stream for life (see Appendix A for details).

\section{Results for the Base Case}

To illustrate how our life cycle model works, we refer to the base case results in Figure 1. Average consumption increases with age in the top panel, since workers are not able to borrow against future labor income. Consistent with empirical evidence, ${ }^{8}$ consumption drops sharply around the retirement age and continues to decrease thereafter. The model also generates a relatively realistic work hours profile by age, as reported in the second panel. Younger workers in their 20's and 30's work more than 40 hours per week. Individuals in their 40's (50's) devote about 40 (35) hours per week to their jobs; after that, they sharply cut back on average work hours and start to retire from full-time employment. ${ }^{9}$ The third panel reports asset allocation patterns by age. For those aged $20-30$, the bond fraction is $60 \%$, somewhat higher than found in empirical work. Yet from their 30's onward, individuals hold about 30-40\% of their wealth in bonds, and 60-70\% in stocks; these ratios are in line with empirical evidence. ${ }^{10}$ Overall, our life cycle model is able to generate consumption, work, and investment patterns that accord reasonably well with empirical evidence.

\section{Figure 1 here}

Next we examine how the two different delayed retirement schemes affect results in the base case for individuals initially age 20 (left side of Figure 1) versus age 60 (right side). Offering a lump sum Social Security instead of a larger benefit payment for deferred retirement changes life cycle consumption, work hours, and investment patterns. For the younger group,

\footnotetext{
${ }^{8}$ See Bernheim, Skinner and Weinberg (2001), Banks, Blundell, and Tanner (1998), Battistin, Brugiavini, and Weber (2009), and the discussion in Chai, Horneff, Maurer, and Mitchell (2011).

${ }^{9}$ For more on this point see Chai, Horneff, Maurer, and Mitchell (2011).

${ }^{10}$ See for example Gomes and Michaelides (2005).
} 
consumption and work hours do not respond much until they reach their 60 's. At that point, those who will receive the lump sum can consume more and enjoy less leisure. This occurs because the lump sum can be spent as well as invested, potentially earning a market return that permits more spending. Additionally, this higher consumption is traded off for less leisure at older ages (more work hours). Overall, asset allocation under the two scenarios is also quite similar, though after age 60 , having the lump sum leads to a slightly higher equity exposure and hence slightly lower bond fraction. Similarly, for those age 60 when the lump sum is introduced, consumption and work hours increase, while bond holdings fall slightly.

Additional detail on retirement patterns is provided in Table 1, where young people knowing they will receive a lump sum for deferred retirement - shift rather markedly toward later retirement. In fact, the left panel indicates that the average retirement age rises by 1.8 years (from 64.5 to 66.3 ); the probability of claiming benefits after the NRA rises from $29 \%$ to $86 \%$. Among those already age 60 when the lump sum scenario is implemented (right panel), the average retirement age again rises, though by a bit less, 1.4 years (from 63.5 to 64.9). While most older workers do claim benefits by age 68, their probability of working beyond the NRA rises substantially, from $4 \%$ to $49 \%{ }^{11}$

\section{Table 1 here}

\section{Sensitivity Analysis}

Thus far, results for the base case provide support for the conclusion that providing a lump sum instead of an increased annuity benefit for deferred retirement under Social Security would induce people to work longer. Next, in sensitivity analyses presented in Table 2, we explore what

\footnotetext{
${ }^{11}$ Table 1 shows two spikes in retirement frequency, at ages 63 and 66 (for the group initially age 20). These are slightly later than the two retirement peaks at age 62 and 65 reported by Gustman and Steinmeier (2005). Yet that study denotes people as retired if they leave full-time work, while we assume that individuals claim retirement benefits and move to full leisure at the same age. If we define retirement as working less than 20 hours per week, this would shift retirement rates earlier.
} 
happens when key preference parameters are changed. In addition, we analyze the impact of two other potential changes in the Social Security rules, reported in Panel A. Finally, Panel B illustrates the policy impacts on households who do not access the equity market.

Table 2 here

Several alternative calibrations for preference parameters are provided in Table 2, to be compared with the average retirement age results for the base case as well as the estimated probability of working beyond the normal retirement age. Interestingly, workers with a moderate versus a strong bequest motive ( $b=2$ or 5 in Panel A), compared to the base case without bequests, behave relatively similarly when given a lump sum instead of a delayed retirement annuity. Thus young workers seeking to leave a bequest would defer retirement by 1.9 years, on average, versus 1.8 if they had no interest in bequests; the older group would boost its retirement age by 1.3 years versus 1.4 with no bequest motive. It is also worth noting that the probabilities of working beyond the NRA are comparable across the board. In sum, even when workers have a bequest motive, the delayed retirement impact of the reform is similar. Accordingly, providing a lump sum does not simply result in wealth transfers to one's heirs, consistent with the rationale for Social Security as a national social insurance scheme intended to support consumption for the elderly.

The next six rows of Panel A in Table 2 illustrate how results change for lower/higher subjective discount rates, lower/higher risk aversion, and lower/higher levels of tastes for leisure versus consumption. Less patient younger and older workers $(\beta=0.96)$ will chose to retire earlier as compared to the base case, but the lump sum reform still induces more to work beyond the normal retirement age, and on average retirement ages rise. As discount rates fall, those who are more patient $(\beta=0.99)$ will work longer than in the base case, with an average increase of over one year in the retirement age; here too, the lump sum induces later retirement. Turning next 
to differences by level of risk tolerance, older workers who are not particularly risk averse ( $\rho=$ 2) will retire at the same age as in the base case. Yet offering them the lump sum instead of the delayed annuity credit produces a much larger impact on retirement ages: on average, the retirement age rises by 3.3 years compared to 1.3 in the base case. A young household with low risk aversion retires 1.8 years earlier on average than the base case household but delays retirement by a comparable 1.6 years in the lump sum regime. Early retirement is also the norm for the extraordinarily risk averse $(\rho=8)$, under any of the circumstances depicted. This is because such individuals tend to work very hard and save a great deal at younger ages to protect against shocks; then, as they approach their 60 's, they favor certain leisure and early retirement instead of worrying about not being able to consume due to uncertain mortality. Additionally, offering them a lump sum has hardly any effect on retirement behavior.

Next we turn to two alternative formulations for leisure preferences: one individual values consumption much more highly $(\alpha=0.7)$ than in the base case, and the other values leisure more $(\alpha=1.9)$. Here, the lump sum reform has virtually no impact. That is, leisure lovers still quit work early, and those who strongly prefer consumption still retire later since longer worklives generate more spendable income.

The final two rows of Panel A in Table 2 examine the impact of two variations on Social Security system parameters. Not surprisingly, if the Social Security benefit replacement rate were reduced from $\lambda=60 \%$ to $45 \%$, retirement ages rise substantially. Those who have a lifetime to adjust, who are initially age 20, work 2.7 years longer, and the older group works 3.3 more years. In both instances the probability of working over the NRA exceeds $90 \%$. This result obtains regardless of whether the delayed retirement credit is replaced by the lump sum. In our second policy variant, we raise the NRA from 65 to 67 for those initially age 20. This again would raise the average retirement age in the annuity regime, but moving to the lump sum scenario would 
have hardly any additional impact on retirement behavior.

If the aim is to raise retirement ages, the last two policies work in the same direction as replacing the delayed retirement credit with a lump sum as described above. Yet cutting the replacement rate and raising the NRA will be politically unpopular, since these represent benefit reductions; offering the lump sum does not represent a benefit cut but a rather a change in the timing of benefit receipt.

To this point, we have assumed that consumers have access to the equity market if they wish to allocate their portfolios across risky and risk-free assets. Panel B illustrates results if consumers do not access the equity market. This might be the case for people who are not financially savvy due to lack of time, information, or the requisite guidance on how to buy stock. We call this group the financially unsophisticated, consistent with van Rooij, Lusardi and Alessie (2011) who show that those who lack financial literacy do not invest in the stock market. It is well known that some $50 \%$ of households do not participate in the stock market today (SCF, 2012; Gomes and Michaelides, 2005); hence for this group, this second set of results could be relevant.

Once again, we evaluate how retirement ages would change if the lump sum were offered in lieu of the Social Security delayed benefit. The first row indicates that, in the base case, both the young and the old would retire later than in Panel A. But giving workers a lump sum for deferred retirement instead of an increased annuity would be less effective in inducing prolonged work at older ages.

The second row of Panel B indicates that people who love risk $(\rho=2)$ worry less about smoothing consumption, so for them the lump sum induces longer work and higher consumption. By contrast, for extremely risk averse younger individuals $(\rho=8)$, the reform has again the opposite incentive: they retire earlier and have a much lower probability of working beyond the 
Normal Retirement Age. This can be explained by the fact that the financially unsophisticated place a high value on the Social Security annuity as it allows them to smooth consumption and also protects against longevity risk. These individuals cannot replicate the benefit stream by investing the lump sum in the bond market. Evidently, boosting Americans' level of financial literacy would help strengthen the incentive effects of a lump sum reform.

\section{Welfare Implications}

Finally we turn to an analysis of the welfare implications of replacing the delayed retirement benefit with a lump sum. The approach evaluates how much additional wealth (as a percent of first-year labor earnings) the individual would need under the current regime, to be as well off as under the lump sum regime. Accordingly, a positive value implies the reform is welfare enhancing, while a negative value implies the opposite.

Table 3 reports the results for various parameterizations of people initially age 20 and age 60 when the reform is implemented. In the base case, the change in welfare for the young is miniscule (10 basis points). For those age 60 when the reform is implemented, the change in lifetime utility is valued slightly positively, at $4 \%$. Under alternative preference settings, there is virtually no impact on the young - the welfare changes in all cases do not exceed $-1 \%$. Moreover, the young financially unsophisticated also experience almost no change in utility, with the exception of the very risk averse, where lifetime welfare declines by $10 \%$ of the initial labor income.

\section{Table 3 here}

Turning to the older group (initially age 60), welfare impacts are all positive but relatively small (below 5\%) in most cases. One exception is for the risk-lover $(\rho=2)$ who has access to the stock market. Here, the consumer's welfare gains amount to a substantial $29 \%$, because she can 
trade off higher consumption levels early in retirement in exchange for lower consumption later (when mortality risk increases). Moreover she has access to the equity market and can invest part (or all) of the lump sum. The welfare gain is much lower $(18 \%)$ when the worker does not invest in the equity market.

For two groups of older individuals, welfare rises under the lump sum regime, but there is little impact on retirement (see Table 2). Those with little taste for leisure $(\alpha=0.7)$ appreciate the lump sum but do not change work patterns as compared to the annuity regime; this is because they are already willing to work a long time (up to age 70 , in some cases) to finance their high consumption needs. Their lengthy worklives generate high lump sum payments for the delayed retirement credit, which in turn can be invested in the stock market and used to boost consumption. The welfare gains of a lump sum payment compared to higher annuity benefits disappears for 60 -year old work lovers $(\alpha=0.7)$ with no access to the stock market. ${ }^{12}$

The retiree with a less generous replacement ratio $(\lambda=0.45)$ profits by receiving the delayed retirement credit as a lump sum instead of a higher lifelong pension (welfare rises by 22.3\%). Again, the reform has little impact on work effort, because in both cases the retiree is willing to work longer to compensate the lower replacement rate. Rather the welfare improvement results again from the possibility to invest the lump sum in the stock market. ${ }^{13}$

In general, the lump sum reform offers an incentive for people to trade off more consumption for less leisure, by working longer and deferring retirement. Overall, this reform has little impact on the young, relatively speaking, and it slightly enhances welfare among the older population. Accordingly, such a reform could be an appealing alternative to encourage longer worklives.

\footnotetext{
${ }^{12}$ Such preferences for very long worklife may not be relevant for the broader population, but they would apply to tenured university professors (Ashenfelter and Card, 2002).

${ }^{13}$ For consumers lacking access to the stock market, the welfare gain is positive but small (less than $2 \%$ ).
} 


\section{Conclusions}

This paper has explored whether people might voluntarily work longer if they were offered a lump sum instead of a delayed retirement annuity under Social Security. We adopt a realistically calibrated life cycle model with forward looking rational agents with endogenous labor supply, saving, investment, and retirement decisions, and allowing for time-varying investment opportunity sets and risky labor income. This model generates consumption, work, and investment profiles, relatively consistent with empirical evidence.

We show theoretically that substituting a lump sum for the delayed Social Security annuity provides an incentive for many workers to voluntarily defer retirement, with little reduction in lifetime welfare. In other words, giving workers a lump sum at their delayed retirement date permits them to adjust the timing of their consumption and leisure time to adapt their preferences. People who receive their delayed retirement credit as a lump sum payment should optimally boost their average retirement age by 1.5-2 years. Having a lump sum in lieu of a higher lifetime Social Security benefit allows retirees to shift consumption to the earlier phase of retirement when mortality risk is low. In addition, the lump sum payment permits households to participate in the stock market, seeking to earn the risk premium. These results hold whether or not workers have a positive bequest motive, implying that the lump sum does not simply result in wealth transfers to theirs. Households without access to the equity market are less responsive to the lump sum option, but even here, the less risk-averse also work longer and retire later, and the lump sum policy generally does not detract from well-being.

In years to come, US policymakers will be actively seeking ways to reform Social Security to restore the system to solvency. Proposing cuts in benefits tends to be quite politically difficult. By contrast, offering a fair lump sum in place of the delayed retirement annuity credit 
may be more politically attractive. By (voluntarily) delaying their retirement date due to the lump sum option, workers would continue to pay Social Security payroll taxes for more years, which could help return the system to solvency via additional payroll tax collections. Moreover, such a policy could be designed to be cost-neutral, albeit in the real world one would also need to consider additional issues including spouse and survivor benefits, changes in annuity factors, sudden demands for liquidity due to health shocks, and other factors. These are all avenues of future research. 


\section{References}

Ashenfelter, O. and D. Card (2002). Did the Elimination of Mandatory Retirement Affect Faculty Retirement? American Economic Review 92: 957-980.

Banks, J., R. Blundell, and S. Tanner (1998). Is There a Retirement-Savings Puzzle? American Economic Review 88: 769-88.

Battistin, E., A. Brugiavini, E. Rettore, and G. Weber (2009). The Retirement Consumption Puzzle: Evidence from a Regression Discontinuity Approach. American Economic Review 99: 2209-26.

Bernheim, B. D., J. Skinner and S. Weinberg (2001). What Accounts for the Variation in Retirement Wealth among U.S. Households? American Economic Review 91: 832-857.

Brown, J., A. Kapteyn, and O. S. Mitchell (2011). Framing Effects and Expected Social Security Claiming Behavior. NBER WP-17018.

Brown, J., J. Kling, S. Mullainathan, and M. Wrobel (2008). Why Don't People Insure Late Life Consumption? A Framing Explanation of the Under-Annuitization Puzzle. American Economic Review 98: 304-309.

Calvet, L.E., J.Y. Campbell, and P. Sodini (2009). Measuring the Financial Sophistication of Households. American Economic Review: Papers and Proceedings 99: 393-98.

Chai, J., W. Horneff, R. Maurer, and O. S. Mitchell (2011). Optimal Portfolio Choice over the Life Cycle with Flexible Work, Endogenous Retirement, and Lifetime Payouts. Review of Finance 15: 875-907

Chai, J., R. Maurer, O. S. Mitchell, and R. Rogalla (2012). Lifecycle Impacts of the Financial and Economic Crisis on Optimal Consumption-Portfolio Choices, and Labor Supply. In: R. Maurer, O. S. Mitchell, and M. Warshawsky (ed.), Reshaping Retirement Security: Lessons from the Global Financial Crisis, Oxford University Press, Oxford, UK, Chapter 7. 
Consumer Expenditure Survey (2012). US Bureau of Labor Statistics. http://www.bls.gov/cex Davidoff, T., J. Brown, and P. Diamond (2005). Annuities and Individual Welfare.” American Economic Review 95: 1573-1590.

Fehr, H., S. Jokisch, and L.J. Kotlikoff (2006). Will China Eat our Lunch or Take Us Out to Dinner? Simulating the Transition Paths of the US, EU, Japan and China. In I. Takatoshi and A. K. Rose (Eds.). Fiscal Policy and Management in East Asia. Chicago, University of Chicago Press: 133-198.

Feldstein, M. and J. Liebman (2002). Social Security. In: Auerbach, A.J., Feldstein, M. (Eds.), The Handbook of Public Economics, vol. 4. Chapter 32. Elsevier.

Fetherstonhaugh, D. and L. Ross (1999). Framing Effects and Income Flow Preferences in Decisions about Social Security. In: Behavioral Dimensions of Retirement Economics ed. H. J. Aaron, Brookings Institution Press 1999: 187-209.

Gomes, F., L. Kotlikoff, and L.M. Viceira (2008). Optimal Life Cycle Investing with Flexible Labor Supply: A Welfare Analysis of Life Cycle Funds. American Economic Review: Papers \& Proceedings 98: 297-303.

Gomes, F. and A. Michaelides (2005). Optimal Life Cycle Asset Allocation: Understanding the Empirical Evidence. Journal of Finance 60: 869-904.

Gustman, A. L. and T. L. Steinmeier (2005). The Social Security Early Entitlement Age in a Structural Model of Retirement and Wealth. Journal of Public Economics 89: 441- 463. Laitner, J. and D. Silverman (2012). Consumption, Retirement and Social Security: Evaluating the Efficiency of Reform that Encourages Longer Careers. Journal of Public Economics. 96: 615-634.

Lusardi, A. and O. S. Mitchell (2007). Baby Boomer Retirement Security: The Roles of Planning, Financial Literacy, and Housing Wealth. Journal of Monetary Economics 54: 205-224. 
Mitchell, O.S. and J. Phillips (2006). Social Security Replacement Rates for Alternative Earnings Benchmarks. Benefits Quarterly 4: 37-47.

Mitchell, O. S., J. Poterba, M. Warshawsky, and J. Brown (1999). New Evidence on the Money's Worth of Individual Annuities. American Economic Review 89: 1299-1318.

Orszag, P. R. (2001). Should a Lump-Sum Payment Replace Social Security Delayed Retirement Credit? Issue Brief No. 6 April 2001, Center for Retirement Research at Boston College. van Rooij, M., A Lusardi, and R. Alessie (2011). Financial Literacy and Stock Market Participation. Journal of Financial Economics 101: 449-472.

Shoven, J. B. and S. N. Slavov (2012). When Does it Pay to Delay Social Security? The Impact of Mortality, Interest Rates, and Program Rules. NBER WP 18210.

Storesletten, K., C. I. Telmer, and A. Yaron (2004). Cyclical Dynamics in Idiosyncratic Labor Market Risk. Journal of Political Economy 112: 695-717.

Survey of Consumer Finances. (2012). 2010 SCF Chartbook. http://www.federalreserve.gov/econresdata/scf/files/2010_SCF_Chartbook.pdf

Warner, J., and S. Pleeter (2001). The Personal Discount Rate: Evidence from Military Downsizing Programs. American Economic Review 91: 33-53.

Yaari, M. (1965). Uncertain Lifetime, Life Insurance, and the Theory of the Consumer. Review of Economic Studies 32: 137-150. 


\section{Appendix A: The Life Cycle Model}

We build on the framework developed and calibrated by Chai, Maurer, Mitchell, and Rogalla (2012). Stock returns and labor earnings are driven by a Markov-Regime-Switching process for the business cycle with two states: normal $\left(s_{t}=0\right)$, or contraction $\left(s_{t}=1\right)$. The consumer observes the current state and knows the (constant) conditional transition probabilities $\pi_{i, j}^{B C}:=\mathrm{P}\left(s_{t+1}=j \mid s_{t}=i\right)$ to be at time $t+1$ in state $j$, given that at time $t$ the economy is in state $i$. Using US Gross National Product data, we estimate the transition probabilities between the two states as $\pi_{0,0}^{B C}=\pi_{0,0}^{B C}=0.68$ and $\pi_{0,0}^{B C}=\pi_{0,0}^{B C}=0.32 .{ }^{14}$ Capital markets include riskless bonds with gross return $R_{f}=1.02$ and risky stocks. Log stock returns $\ln \left(R_{s, t+1}\right) \sim N\left(\mu_{i}, \sigma_{i}\right)$ are normally distributed with state dependent parameters by either being in a normal capital market regime with low volatility $\left(\sigma_{0}=11.21\right.$ percent $)$ and high expected returns $\left(\mu_{0}=6.84\right.$ percent), or a contraction regime with high volatility $\left(\sigma_{1}=\right.$ 20.77 percent) and low expected returns ( $\mu_{1}=2.12$ percent). Income on assets is taxed according to the proportional rate $\theta^{c}$, which we set to 20 percent.

The labor income process allows for unemployment risk and state-dependent wage rate dynamics. The individual receives uncertain labor income depending on what fraction of available time is devoted to work $\left(1-L_{t}\right)$ and a state dependent wage rate $W R_{s_{t}, t+1}$. Earnings from the labor market are reduced by an age-dependent fraction $q_{t+1}$ of housing related expenditures, estimated using data from the Consumer Expenditure Survey (or CES) as shown in Appendix B. In addition, the worker must pay income taxes according to a proportional tax rate $\theta^{l}$ equal to 30 percent. Thus disposable yearly labor earnings before the (endogenous) retirement age $(\mathrm{t}<\tau, \tau \in[62,63, \ldots, 70])$ are given by:

\footnotetext{
${ }^{14}$ As in Storesletten, Telmer, and Yaron (2004) a contraction (expansion) state occurs when the GNP growth rate was less than (greater than) its sample period mean.
} 


$$
Y_{s, t+1}^{E}=\left(1-q_{t+1}\right) \cdot\left(1-\theta^{l}\right) \cdot W R_{s, t+1} \cdot\left(1-L_{t}\right)
$$

Here $L_{t}=[1 / 3,1]$ stands for leisure and is measured as a percentage of available time. To transfer normalized leisure into work hours we assume 100 waking hours per week. The exogenously determined wage rate process is given by $W R_{s, t+1}=\exp \left(w_{t+1}\right) \cdot E_{s, t+1} \cdot U_{t+1}$. The deterministic trend component $w_{t+1}$ is calibrated using the earnings function reported in Fehr, Jokisch, and Kotlikoff (2006) for middle-income workers, ${ }^{15}$ and it is scaled to generate an average gross labor income of $\$ 20,000$ at age $20 . \ln \left(U_{t+1}\right) \sim N\left(0, \sigma_{u}\right)$ is a state-independent transitory shock ( $\sigma_{u}=32.9$ percent), ${ }^{16}$ and $E_{s, t+1}=E_{s, t} n_{s, t+1}$ is a state-dependent permanent labor earnings component, with $\ln \left(n_{s, t+1}\right) \sim N\left(0, \sigma_{n, s}\right)$. We follow Storesletten, Telmer, and Yaron (2004) and set the state dependent volatility $\sigma_{n, s}$ of permanent wage rates shocks in the normal state to $\sigma_{n, 0}=8.4$ percent, which is lower than in the contraction scenario $\sigma_{n, 1}=15.9$ percent. The correlation between stock returns and permanent and transitory earnings shocks $\phi$ for both cases is set to 0.2 .

The worker could be unemployed in the next period, where the state-dependent probability of unemployment $\pi_{s}^{U}$ is again lower in the normal state ( $\pi_{0}^{U}=5$ percent) than in the contraction state $\left(\pi_{1}^{U}=10\right.$ percent). In such a situation, the worker receives unemployment compensation at time $t+1$ specified as a set fraction of labor income, i.e., $Y_{s, t+1}^{U}=0.6 \cdot Y_{s, t+1}^{E}$.

The model allows a flexible retirement age, i.e., the worker can claim a Social Security benefit payable for life at any age between the early retirement age $(E R A=62)$ and the latest retirement age $(L R A=70)$. Once benefits are claimed, the individual does not return to the workforce. If the worker claims prior to the normal retirement age $(N R A=65)$, the benefits are

\footnotetext{
${ }^{15}$ Precisely, we use equation (9) with parameter $\lambda=0$ which produces a humped shaped trend function for wages rates: $\mathrm{w}($ age $)=\exp \left(4.47+0.033 *\right.$ age $\left.-0.00067 * \mathrm{age}^{2}\right)$.

${ }^{16}$ The volatility of the transitory shock is estimated by averaging the fixed effect and measurement error from Storesletten, Telmer, and Yaron (2004).
} 
permanently reduced for each year of early retirement according to the reduction factor $g_{1}=0.0713$. If the individual works longer than the NRA, the Social Security benefit is increased per year of additional work by the delayed retirement credit $g_{2}=0.077$ (see Buchinsky, Rust, and Benitez-Silva 2000). To capture this feature, we calculate the after-tax Social Security benefits as in Chai, Horneff, Maurer, and Mitchell (2011):

$$
Y_{t}=\left(1-q_{t}\right)\left(1-\theta^{r}\right) \bar{Y} \lambda F_{\tau, N R A}
$$

where is $F_{\tau, N R A}=\exp \left(-g_{1}(N R A-\tau)\right) \cdot I_{\{\tau \leq N R A\}}+\exp \left(-g_{2}(N R A-\tau)\right) \cdot I_{\{\tau>N R A\}}$ a factor which specifies the reduction/increase of retirement benefits if the individual retires prior/later to the NRA. The parameter $\lambda$ is the Social Security replacement rate (here set to 60 percent as in Mitchell and Phillips 2006) based on the worker's lifetime average earnings approximated by $\bar{Y}=\left(\sum_{t=1}^{K}(1-\right.$ $\bar{L}) \exp (w(t)) / K) \cdot E_{K}$. Here $K$ denotes when the individual attains the normal retirement age (NRA) and $1-\bar{L}$ stands for the average working time until retirement, which we set equal to 0.4 corresponding to a lifetime work effort of 40 hours per week on average. As in Gomes, Kotlikoff, and Viceira (2008) Social Security benefits are taxed at a proportional rate of $\theta^{r}=15$ percent.

Alternatively, we posit that the individual can receive the delayed Social Security retirement benefit as a lump sum payment, instead of an increase in lifelong annuity benefits. In this case, the lump sum payment is calculated as the actuarial present value of the additional annuity benefits generated by working longer than the normal retirement age. Formally the lump sum payment is given $(t>N R A)$ as follows:

$$
L S_{t}=\left(1-\theta^{r}\right) \cdot \bar{Y} \lambda\left(F_{\tau, N R A}-1\right) \cdot \ddot{a}_{t}
$$

Here $\ddot{a}_{t}=1+\sum_{m=1}^{T-1}\left(\prod_{u=t}^{t+m-1} p_{u}\right) \cdot R_{f}^{-m}$ is the actuarial present value factor based on the riskless interest rate $R_{f}$ and the one year survival probabilities $p_{t}$ (i.e., to survive to time $t+1$ given being alive at $t$ ). 
The following table illustrates the possible lump sum payments for delaying retirement as percentage of benefits at age 65 (ceteribus paribus). To calculate them, we use a riskless interest rate of $2 \%$ per annum (as in our life cycle model) and the US 2000 population mortality table for females. Further, we normalize the lump sum payments given in equation (A-3) by $\left(1-\theta^{r}\right) \bar{Y} \lambda$. In addition, we report the delayed retirement credits $F_{\tau, N R A}$ if the worker receives the additional benefits as a lifelong annuity.

\begin{tabular}{lccccc}
\hline & \multicolumn{5}{c}{ Retirement Age } \\
& 66 & 67 & 68 & 69 & 70 \\
\cline { 2 - 6 } & & & & & \\
Life Annuity (in \% of NRA benefit) & 8.0 & 16.6 & 26.0 & 36.1 & 46.9 \\
Lump Sum (in \% of NRA benefit) & 119.0 & 239.2 & 360.0 & 481.1 & 602.9 \\
\hline
\end{tabular}

Each period, the consumer decides how much to work $\left(1-L_{t}\right)$ to generate labor income, when to retire, and how to allocate cash on hand $W_{t}$ to bonds $B_{t}$, stocks $S_{t}$, and consumption $C_{t}$. The budget constraint is given by:

$$
W_{t}=S_{t}+B_{t}+C_{t}
$$

and next period's wealth $W_{t+1}$ is described by:

$$
W_{t+1}=\left(S_{t} R_{s, t+1}+B_{t} R_{f}\right)\left(1-\theta^{c}\right)+\theta^{c}\left(B_{t}+S_{t}\right)+Y_{s, t+1}
$$

Here, $Y_{s, t}$ is labor income as defined in equations (A-1) and (A-2). This is the state-dependent net labor income (or unemployment benefits) prior to claiming and the Social Security benefits after claiming. In case the household claims after the NRA, the delayed retirement credit is paid in the form of a lump sum, and $g_{2}$ in equation (A-2) is set to zero when calculating the lifelong benefits from Social Security. In this situation, the wealth transition equation at the time of claiming, $\bar{t}$, is given by:

$$
W_{t+1}=\left(S_{t} R_{s, t+1}+B_{t} R_{f}\right)\left(1-\theta^{c}\right)+\theta^{c}\left(B_{t}+S_{t}\right)+Y_{s, t+1}+L S_{t+1}
$$


Here $L S_{t}$ is the lump sum payment according to equation (A-3) the household receives at time $\bar{t}+1$. In subsequent periods $(t>\bar{t})$, the transition equation is again given by (A-5).

Households cannot borrow against human capital nor can they hold short positions in stocks and bonds $\left(C_{t}, S_{t}, B_{t}, \geq 0\right)$. Moreover, we posit that in order to participate in the stock market, the household has to be willing and able to invest a minimum amount in stocks (as in Smetters and Chen, 2010). This amount is set to $50 \%$ of permanent labor income.

The individual's optimization problem is now to maximize liftetime utility with respect to her asset allocation between bonds and stocks, consumption, work hours, and the retirement decision. After normalizing with permanent labor income there are four state variables: cash on hand $W_{t}$, retirement age $\tau$, the business cycle state $s$, and age $t$. We discretize the (normalized) continuous state variable and solve the optimization problem by backward induction. For computations, we use a grid of dimension $40(\mathrm{~W}) \times 2(\mathrm{~s}) \times 42(\mathrm{t})$ before and $40(\mathrm{~W}) \times 2(\mathrm{~s}) \times 39(\mathrm{t}) \times 9(\tau)$ after the $E R A$. For each grid point we evaluate the policy and value functions using Gaussian quadrature integration and cubic-splines interpolation. 
Appendix B. Construction of Housing-related Expenditure to Income Ratios

The Consumer Expenditure Survey (or CE) is collected by the U.S. Federal government through the Bureau of Labor Statistics, for the purpose of providing a complete range of information on consumer expenditures and income. The survey consists of five interviews on a quarterly basis. At the initial interview, each household must complete a consumption diary over a 2-week span and provide a detailed overview of what it consumes on a daily basis. The subsequent four interviews focus on quarterly expenditures and annual income; expenditures on housing in the current quarter we multiply by four to obtain annual housing expenditures. Our dataset spans the time period 1996 to 2010 and represents a panel over one-period horizons, but different households are interviewed on a year-to-year basis. In total, there were 425,672 interviews of 145,203 unique households over the 15-year period. We consider only households where the head is between ages $20-89$; we omit observations with negative housing expenditures or labor income. In addition, any observation with a housing-expenditure-to-labor-income ratio exceeding one is excluded from the analysis. This leaves 116,015 households and 161,050 yearly observations.

The variables of interest relate to housing expenditures and labor income to generate a ratio of 'Housing Expenditure over Labor Income.' We sought to fit this measure as closely as possible to the specification reported in Gomes and Michaelides (2005). We define annual labor income as FINCBTAX-(INTEARNX+FININCX), described as 'Income before taxes' less 'income from savings and bonds' and 'income from dividends, royalties, etc. ${ }^{17}$ Quarterly housing expenditures are estimated as the sum of the variables HOUSCQ and HOUSPQ, and

\footnotetext{
${ }^{17}$ One might ask why we do not use the income after taxes (FINCATAX). We discovered that, for some households reporting an income of zero (FINCBTAX=0), they still had to pay some taxes so the after-tax income was negative. This poses a problem for computing the ratio of Housing Expenditures to Labor Income.
} 
this we multiply by four to obtain annual housing expenditures. The last pertinent variable for analysis is the age of the reference person, which is AGE.

Next we run a regression of the ratio of housing expenditures to labor income $\left(q_{i, t}\right)$ on age polynomials and an economy dummy. The ratios are computed for each household by taking housing expenditures (mortgage/rent payments, utilities, and housing-related durable expenditures) relative to the before-tax labor income and regressed against a cubic polynomial of age (of the head of the household), and a dummy variable representing an economy that is either normal $(=0)$ or contracting $(=1)$. The regression is as follows:

$$
q_{i t}=\text { constant }+B_{1} * \text { age }+B_{2} * a g e^{2}+B_{3} * a g e^{3}+B_{4} * \text { economy }+\varepsilon_{i t}
$$

Results of this regression analysis are summarized in the following table:

\begin{tabular}{lrrr}
\hline & Coefficient & t-Statistic & Standard Errors \\
\cline { 2 - 4 } Constant & 0.5773585 & 49.51 & 0.011661 \\
Age & -0.0132081 & -17.57 & 0.000752 \\
Age $^{2}$ & 0.0001793 & 11.83 & 0.000015 \\
Age $^{3}$ & $-5.72 \mathrm{E}-07$ & -5.97 & 0.000000 \\
Economy & 0.0016453 & 1.61 & 0.001022 \\
& & & \\
No. of Observations & & & 161,050 \\
R-Squared & & & 0.021 \\
\hline
\end{tabular}

Our results are compatible with observed rates of higher housing spending especially at older ages, unlike Gomes and Michaelides (2005) who assume that housing expenditures are zero over age 80 . 
Figure 1: Impact of Lump Sum vs. Annuity Reward for Delayed Retirement on Consumption, Work Hours, and Investments among the Financially Sophisticated

Age 20

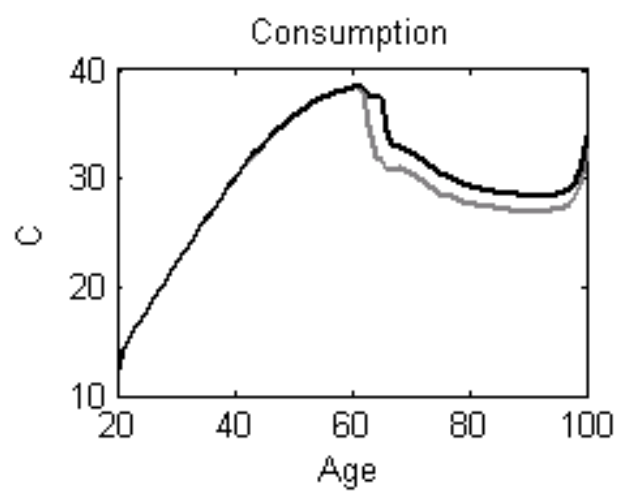

Avg. Work Hours

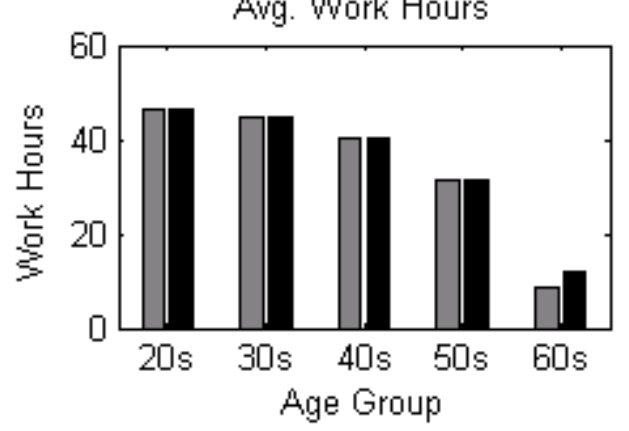

Avg. Bond Fraction

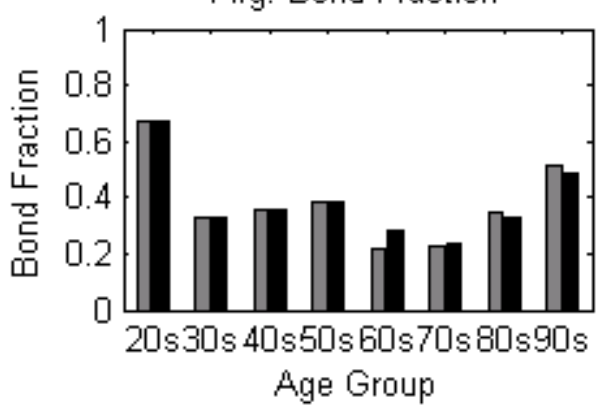

Annuity

Lump Sum

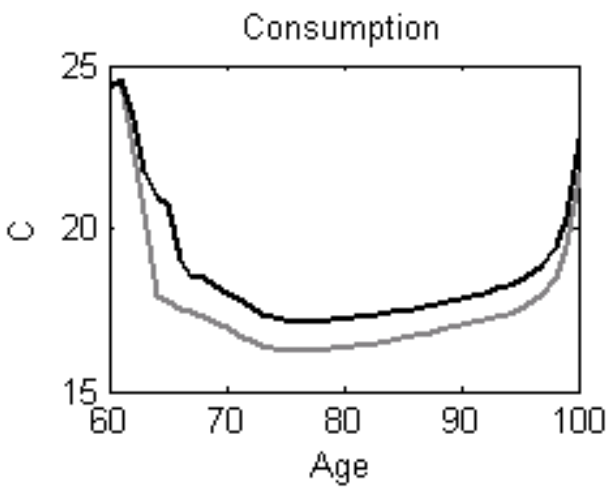

Avg. Work Hours

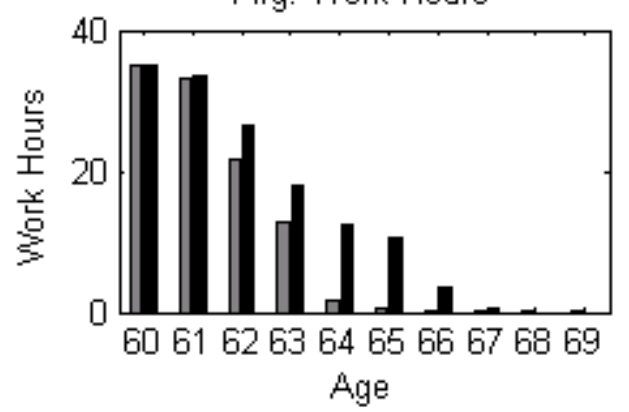

Avg. Bond Fraction

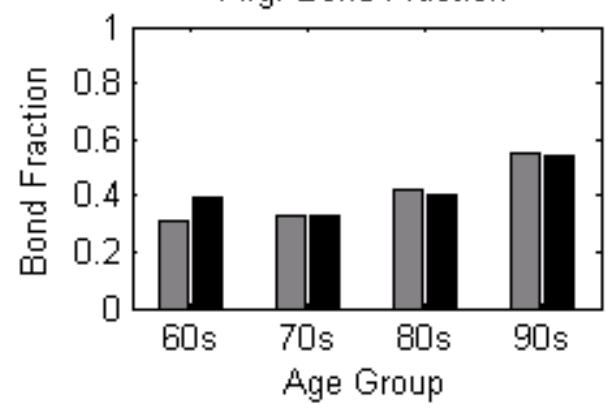

Annuity

Lump Sum

Notes: Expected life cycle profiles for financially sophisticated households with access to the stock market. Annuity: Delayed retirement benefits are paid as a lifelong increase of the pension annuity. Lump Sum: Delayed retirement benefits are paid as an actuarially fair one-time lump sum at retirement. Consumption at various ages reported in USD thousands. Work hours and bond fraction reported as average for different age groups. Base case calibration: relative risk aversion $\rho=5$, bequest motive strength $b=0$, time preference $\beta=0.97$, leisure preference $\alpha=1.3$, normal retirement age $N R A=65$, early retirement age $E R A=62$, latest retirement age $L R A=70$, Social Security replacement rate $\lambda=0.6$. Source: Authors' calculations. 
Table 1: Impact of Lump Sum vs. Annuity Reward for Delayed Retirement on Retirement Age: Base Case

\begin{tabular}{|c|c|c|c|c|}
\hline \multirow[b]{2}{*}{ Age } & \multicolumn{2}{|r|}{ Age 20} & \multicolumn{2}{|r|}{ Age 60} \\
\hline & Annuity & Lump Sum & Annuity & Lump Sum \\
\hline 62 & 1.7 & 1.0 & 14.7 & 8.1 \\
\hline 63 & 30.8 & 5.6 & 36.9 & 22.1 \\
\hline 64 & 26.9 & 4.1 & 37.2 & 17.2 \\
\hline 65 & 11.7 & 3.0 & 7.0 & 3.5 \\
\hline 66 & 19.3 & 46.9 & 3.7 & 29.1 \\
\hline 67 & 7.1 & 20.0 & 0.4 & 14.8 \\
\hline 68 & 2.3 & 19.4 & 0.1 & 5.2 \\
\hline 69 & 0.1 & 0.0 & 0.0 & 0.0 \\
\hline 70 & 0.1 & 0.0 & 0.0 & 0.0 \\
\hline Av. Ret. Age & 64.5 & 66.3 & 63.5 & 64.9 \\
\hline $\mathrm{P}(\mathrm{RA}>\mathrm{NRA})$ & 28.9 & 86.3 & 4.2 & 49.1 \\
\hline
\end{tabular}

Notes: Simulated distribution of retirement ages (frequency in \%) for the base case. Assumed parameters: relative risk aversion $\rho=5$, bequest motive strength $b=0$, time preference $\beta=$ 0.97 , leisure preference $\alpha=1.3$, normal retirement age $N R A=65$, early retirement age $E R A=62$, latest retirement age $L R A=70$, Social Security replacement rate $\lambda=0.6$; financially sophisticated households with access to the stock market. Annuity: delayed retirement benefits are paid as a lifelong increase of the pension annuity. Lump Sum: delayed retirement benefits are paid as an actuarially fair one-time lump sum at retirement. $\mathrm{P}(\mathrm{RA}>\mathrm{NRA})$ : simulated frequency (in \%) of retirement after the normal retirement age. Source: Authors' calculations. 
Table 2: Impact of Lump Sum vs. Annuity Reward for Delayed Retirement on Retirement Age: Alternative Calibrations

\begin{tabular}{|c|c|c|c|c|c|c|c|c|}
\hline \multirow{4}{*}{ A. Financially Sophisticat } & \multicolumn{4}{|r|}{ Age 20} & \multicolumn{4}{|r|}{ Age 60} \\
\hline & \multicolumn{2}{|r|}{ Annuity } & \multicolumn{2}{|r|}{ Lump Sum } & \multicolumn{2}{|r|}{ Annuity } & \multicolumn{2}{|r|}{ Lump Sum } \\
\hline & Av. Ret. Age & $P(R A>N R A)$ & Av. Ret. Age & $P(R A>N R A)$ & Av. Ret. Age & $P(R A>N R A)$ & Av. Ret. Age & $P(R A>N R A)$ \\
\hline & & & & & & & & \\
\hline Base Case & 64.5 & 0.289 & 66.3 & 0.863 & 63.5 & 0.042 & 64.9 & 0.491 \\
\hline \multicolumn{9}{|c|}{ Alternative Household Preferences } \\
\hline$b=2$ & 64.3 & 0.235 & 66.2 & 0.859 & 63.3 & 0.022 & 64.6 & 0.460 \\
\hline$b=5$ & 64.3 & 0.240 & 66.2 & 0.844 & 63.3 & 0.023 & 64.4 & 0.409 \\
\hline$\beta=0.96$ & 64.0 & 0.172 & 65.2 & 0.541 & 63.2 & 0.013 & 63.9 & 0.254 \\
\hline$\beta=0.99$ & 65.4 & 0.536 & 66.4 & 0.887 & 64.0 & 0.136 & 65.7 & 0.738 \\
\hline$\rho=2$ & 62.7 & 0.001 & 64.3 & 0.351 & 63.6 & 0.014 & 66.9 & 0.935 \\
\hline$\rho=8$ & 63.0 & 0.028 & 62.9 & 0.002 & 62.5 & 0.000 & 62.5 & 0.000 \\
\hline$\alpha=0.7$ & 68.8 & 0.955 & 68.3 & 0.934 & 68.1 & 0.993 & 68.3 & 0.995 \\
\hline$\alpha=1.9$ & 62.6 & 0.007 & 62.7 & 0.016 & 62.5 & 0.000 & 62.5 & 0.002 \\
\hline \multicolumn{9}{|c|}{ Alternative Retirement System Parameters } \\
\hline$\lambda=0.45$ & 67.2 & 0.927 & 67.3 & 0.927 & 66.8 & 0.976 & 67.4 & 0.990 \\
\hline$N R A=67$ (for age 20) & 65.3 & 0.068 & 65.6 & 0.187 & na & na & na & na \\
\hline \multicolumn{9}{|c|}{ B. Financially Unsophisticated } \\
\hline Base Case & 67.0 & 0.898 & 66.7 & 0.963 & 63.9 & 0.092 & 64.0 & 0.186 \\
\hline$\rho=2$ & 65.1 & 0.587 & 67.2 & 0.969 & 64.9 & 0.267 & 66.2 & 0.882 \\
\hline$\rho=8$ & 64.2 & 0.257 & 63.7 & 0.091 & 62.7 & 0.001 & 62.7 & 0.000 \\
\hline
\end{tabular}

Notes: Panel A (B) refers to simulated retirement patterns of households with (without) access to the stock market. P(RA $>$ NRA): simulated frequency of retirement ages (RA) older than the normal retirement age (NRA). Annuity: delayed retirement credit paid as increase in Social Security lifetime benefit. Lump Sum: delayed retirement credit paid as an actuarially fair one-time lump sum at retirement. For base case parameters see Table 1. Source: Authors' calculations. 
Table 3: Welfare Implications of Lump Sum vs. Annuity Reward for Delayed Retirement

\begin{tabular}{lrrr}
\hline & Age 20 & Age 60 \\
\cline { 2 - 2 } $\begin{array}{lll}\text { A. Financially Sophisticated } \\
\text { Base Case }\end{array}$ & -0.001 & & 0.041 \\
\multicolumn{3}{l}{ Alternative Household Preferences } & \\
$b=2$ & -0.001 & 0.043 \\
$b=5$ & -0.001 & 0.042 \\
$\beta=0.96$ & 0.000 & 0.028 \\
$\beta=0.99$ & -0.005 & 0.078 \\
$\rho=2$ & 0.000 & 0.289 \\
$\rho=8$ & -0.006 & 0.000 \\
$\alpha=0.7$ & -0.008 & 0.343 \\
$\alpha=1.9$ & -0.001 & 0.000
\end{tabular}

Alternative Retirement System Parameters

\begin{tabular}{lrr}
$\lambda=0.45$ & -0.005 & 0.223 \\
$N R A=67$ & -0.001 & na \\
& & \\
B. Financially Unsophisticated & & \\
Base Case & -0.020 & 0.008 \\
$\rho=2$ & 0.000 & 0.177 \\
$\rho=8$ & -0.101 & 0.000 \\
\hline
\end{tabular}

Notes: Welfare increases (in multiples of labor income as of age 20/60) from paying the delayed retirement credit as an actuarially fair one-time lump sum at retirement instead of an increase in the Social Security lifetime benefit. Base case calibration: relative risk aversion $\rho=5$, bequest motive strength $b=0$, time preference $\beta=0.97$, leisure preference $\alpha=1.3$, normal retirement age $N R A=65$, early retirement age $E R A=62$, latest retirement age $L R A=70$, Social Security replacement rate $\lambda=0.6$. Source: Authors' calculations. 